\title{
RESPONSES OF ACCOUNTABILITY TRANFORMATION PRACTICED IN MULTIPLE LEVEL OF INSTITUTIONAL LOGICS FOR BEING AUTONOMOUS STATE UNIVERSITIES IN INDONESIA
}

\author{
Dwi Cahyo Utomo \\ Universitas Diponegoro \\ dcutomo@lecturer.undip.ac.id
}

\begin{abstract}
This study investigates accountability practices of Indonesian state universities during the reform implementation for being autonomous universites called as PTN Badan Hukum. Although the reform has been implemented based on government regulation, lack of empirical study can be viewed in published articles. For that reason, this study is addresed to filling the lack of accountability research in the reform of state universities in Indonesia. The context of the reform is the adoption of autonomous universities that are more close to the concept of privatisation affected by the internationalization objective of national agenda. Interpretive research approach is adopted to develop inductively a conceptual perspective based on central phenomenon. Moreover, the cases of the study are three Indonesian state universities which implement the form of autonomous state university with pseudo named as UG, UD and UA. Straussian grounded theory approach was adopted in data analysis and collection. The central phenomenon of substantive grounded theory is labelled as multiple accountability responses in various institutional logic during transformation process of state universities that have been transformed from fully governed by Indonesia government become autonomous entities. The main finding of the study explains the presence of various institutional accountibility logics practiced in the context of internationalization process of Indonesia higher education institutions. The various institutional logics arise from personal, professional, managerial and public accountability logics. The various accountability logics display from two different environmental background that are university with less and high internationalization. Less and moderate conflict are resulted from low and high internationalization achievement respectively. The practice of accountability seem displaying more emphasize on public accountability logic in social level, managerial accountability logic in organizational level, personal and professional in individual level. The contribution of this research relates to empirical findings that enrich higher education accountability research in developing countries, employs interpretive methodology and grounded theory, and provides incremental development of institutional logics theory in explaining organizational change in a specific context.
\end{abstract}

Keywords : Indonesian State Universities' Accountability Reform, Interpretive, Multiple Institutional Logics, Grounded Theory

\section{INTRODUCTION}

The concepts of accountability have been enormously investigated during the last three decades resulting different empirical knowledge which was investigated in the various contexts. It could depart from either fundamental or advanced perspectives for understanding accountability practices. Various knowledges of accountability may depend on its circumstances and seem far from universal conclusion. For instance, the comparison of country's setting such as Germany and Britain have showed the 
practice with different accountability style (Ahrens, 1996).

Moreover, accountability is subjectively constructed and changes with context as Sinclair (1995) proposed the chameleon of accountability. For that reason, exploring accountability from practices are continually required as the concept of accountability which is empirically seem circumstantial and cannot be generalised.

\section{THEORITICAL STUDY}

Accountability in public sector was viewed fundamentally as 'the giving and demanding of reasons for conduct' assuming that there is a right of some individual, small group or organization to make not only demands over the conduct of another but also seek reasons for actions (Goddard, 2005). Researchers who stay in this fundamental stream ussually eager to investigate accountability together with another relevant concepts. The accountability research works could be instanced by many scholars in their publication such as Kloot (1999), Budding (2004), and Robinson (2003) focusing on the relationship with government performance; Demirag \& Khadaroo (2008) investigating the link to value for money; Kluvers, (2001b) and Goddard (2004) studying related to budgeting; Monfardini (2010) exploring accountability and public participation. Although the previous researchers start from straightfoward viewpoint, the contribution of studies clearly indicate that accountability relate to behavioural aspect explored from the lived actors' experiences. Behavioral perspective of actors may different among social enviroment where accountability are practiced, therefore contextual analysis of accountability are never ending study.

\section{(Goddard, 2005)}

In the contemporary standpoint, researchers who explore practice of accountability in public sector organisation mostly utilise sociological perspective. They often extend contextual analysis through various sociological lenses either using native sociological theory or employing blend sociological scheme. They mostly employ monolitic sociological theory such as Structuration perspective (Conrad, 2005), institutional analysis ( Abdul-Rahman and Goddard, 2003;); Habitus theory (Goddard, 2004, 2005); Habermas theory (Messner, 2009). Various empirical knowledge have been revealed from those studies presenting rich explanation regarding contextual practice of accountability including its uniqueness which was explained through numerous sociological lenses. These all empirical studies have depicted social context of accountability strongly implicate to its form of practices. 
Numerous context of study in the public sector area and non-government organization have been explored for accountability research almost in the last three decades. The studies of organisation include stated-owned entities (Hoque and Moll, 2001); state religious councils (Abdul-Rahman and Goddard, 2003); government entities (Kluvers, 2001; Robinson, 2003; Budding, 2004; Goddard, 2005; Schaeffer \& Yilmaz, 2008); local management school (Ezzamel et al., 2007). In the country's context of studies can be highlighted such as in the UK public sector (Humphrey et.al, 1993); Australia (Hoque and Moll, 2001); Swedish armed forces (Catasús and Grönlund, 2005); Dutch (Budding, 2004); Nigeria (Iyoha and Oyerinde, 2010). Refer to the previous studies above, it is possible to conclude that most of accountability offer distinctiveness of environment in which the practice from actors are investigated. The more characteristics of accountability's environment that can be explained, the better practice of accountability can be conceptualized. Accordingly, further studies are possible to enrich the uniqueness of accountability circumstances with regard to develop theoretical concept from particular context of accountability practice.

In response to the need for enrichment of context in accountability literature, this research innitially address to focus on accountability practice during implementation of Indonesia higher education reform when some public universities were transformed fully being self-governing university. Accountability is the focused concept of the study which is investigated from the practice in particular circumstance. The context of the study is a situation when some Indonesia public universities, owned and established by government, have become autonomous university as regulated by national law and government regulation. Inspired by the work of Sinclair (1995) that found accountability to be subjectively constructed, this study intend to explore behavioural aspect obtained from the lived actors' experiences.

Generally, the term of accountability is often employed to express the responsibility that those who manage or have control over resources have to others. Accountability is often related to theoretical perspective of agency theory when agents responsible and have to manage resources mandated by principal (Coy and Pratt, 1998). In private sector organisation, the conflict of interest between agent and principal during resources usage in organisation may dominate the critical view of scholars regarding accountability. The issues of accountabilty are mostly related to what extend agent could manage resources 
close to the interest of principal. On the other hand, this agency issues' enquiry may not an appropriate analysis for public sector organisation. In public sector, all those who manage and making decision over public resources are responsible to the public. Principal may not exist directly in the organisation as public are never present straightly inside organisation, then practice of accountability may not depend on interaction between agent and principal. Agents that may consist of actors inside organisation could practice a particular form of accountability that depend on the actors' interpretation. As the principal are external to the organisation, therefore agent may interprete accountability based on sociological reasons instead of psycological perspective such as economic motives and interest. The context in which actors' lived experience may govern practice accountability.

The context of study stress on a distinctive enviroment where some Indonesia higher education institutions experience a situation of organisational change trasformed from fully controlled by central government become autonomous public university. Reffering to national law 12/2012 article no 65, an autonomous public university, known as PTN Badan Hukum (BH), has been given distinct right to manage independently their resources and make their own decision without any intervention from government. The role of central government are the owner of university but could not controll fully in managerial decision making. The interest of government for PTN Badan Hukum are not only the ability of university to fulfill internationalization demand and world class universities pressures but also in providing reasonable tuition fee for the public. In such situation, accountability demand seem differ from the previous form of public universities, therefore actors may interprete and perform differently, hence influencing the practice of accountability. Moreover, lack of theoretical explanation regarding the accountability in such context is another rationalization of the study.

Refer to the focused concept and the unique context, this study initially intends to understand accountability practice in Indonesian public university which become autonomous university. Moreover, this study also expect to provide contribution as a case of a less developed country. The case address to illuminate a less developed country experience which might differ from the case of developed country. Inspiration of the study begins from the need to obtain in-depth understanding of activities inside organization viewed as a social subjective reality. Consequently, investigating accountability practice in organizational context should be taken from the perspective of those who involve it. As 
interpretive accounting research, this study has been motivated and built fundamentally on inspiring methodological debates of Hopper \& Powell (1985) and Chua (1988) by investigating social world of accounting to capture more accurately the lived actors' experiences with particular context of Indonesian public university. In addition, the Straussian grounded theory method was adopted to accompany the interpretive methodology with regard to the study's intention for theory generation from phenomena being investigated.

\section{RESEARCH METHODS}

The whole research project is the implementation series of grounded theory in non-profit organisation accounting research. The procedures relevant to the study's grounded theory began with the research context prepared through the presentation of a literature review. The grounded theory research has been viewed as powerful method to generate inductively a theory from data in accounting researches (e.g Elharidy et al., 2008; Tillmann and Goddard, 2008; Goddard and Mzenzi, 2015). Inspired with the approach of Strauss and Corbin (1990), the subject of the study was defined, and then appropriate research sites are identified and approached for access. In-depth interview combined with observation and archives document were analysed through systematic coding named as open, axial and selective codes. These three coding analysis were conducted for generating subtantive theory which is constructed inductively from data.

Data were collected initially from five events of official forum group discussion (FGD) among 11 universities grouped as PTN BH. Researchers were also participant observer during the discussion. Next, the initial data were complemented with indepth interview data from the field study of three universities. The field research was selected with several reasons. One of the observed public university already implementing PTN-BH longer than the other and part of first batch of PTN BH establisment. The other two are PTN BH implementing the reform in the same batch during the organisational translation.

The research field are chosen to support the implementation of grounded theory as a research method. For ethical purposes, the names of observed universities are presented under the pseudonyms of DU, UA and UG. Specifically, DU is the university of the researchers' place of work as this research also utilize participant observer. The other universities are observed through the access of researcher as member of PTN BH officers which have regularly official meeting at least every three months. DU and UA are not included in top 500 global university rank while UG 
is part of the top 500 of QS university world rank. The access is obtained from colleague of researchers who are currently appointed as key officers of the reform process in all observed PTN BH.

Initial research questions are developed after conducting data analysis of forum group discussion (FGD) conducted at least every three month and pilot studies in DU through participant observer. Via the pilot study, the researchers interviewed the most influential or key actors who could provide further access to the field particularly to the person who act as Chief Financial Officers (CFO) of the three observed universities. The other participant of each observed universities comprise four key officers as representation of managerial office, and five persons as lecturer. Therefore, total interviewee are 30 participants.

The initial research inquiries, developed after conducting the pilot study and data analysis of FGD. During the research process, the initial inquiries were refocused and modified during data collection and data analysis to reflect primary actors' concerns, instead of focusing on any particular pre-existing theory (Parker and Roffey,1997). The emergent research themes are allowed to influence iteratively the process of data collection and data analysis. Therefore, initial research questions, and emergent research themes are generated iteratively with refocusing interview questions conducted during data collections. The study of accountability transformation of public universities have identified the co-existence of multiple institutional logics in the organisational field during grounded theory data analysis. As an emerging theme of the study, actors' perceptions about accountability cannot be separated with the presence of accountability reform based on various institutional logics in the context of PTN Badan Hukum (PTN BH). The research principally focuses on accountability practice during implementing its new role as autonomous public universities. As an emerging central phenomenon, the study further investigated responses of various accountability logics in two different type of organizational field that are the existence of moderate conflict and extensive conflict related to the universities' internationalization achievement.

\section{Literature Review}

As a grounded theory study, the intention of this literature review is not to synthesise a hypothesis or determine a proposed theoretical framework for empirical analysis. With intention firstly to support background of the research and secondly to provide theoretical lens of the emergent theme, this section provides a broad discussion of institutional logics, accountability reform related to 
institutional logics, the presence of multiple institutional logics and the role of agent in institutional change.

\section{Institutional logics}

Terminology of institutional logics in organizational studies emerge in published papers of institutionalist researcher more than two decades. Friedland and Alford (1991) propose the value of institutional logics that provide organizing principles for a field. Actors' behaviour in the organizational field are guided by their institutional logics. Institutional logic is a belief systems as common guiding decision-making principle of actors that predominate in an organizational field ( Lounsbury 2008; ter Bogt \& Scapens 2009; Scott 2014). Logics are an essential theoretical concept as they help to clarify connections that create a sense of common purpose and unity within an organizational field (Reay and Hinings, 2009).

In fact, institutional scholars have claimed that organizational fields are controlled by a governing institutional logic whereas two or more institutional logics may exist at the same time (Thornton and Ocasio, 1999). Institutional change may fundamentally exist if there is dominant logics in the organizational field. Most institutional researchers accept as common belief that institutional change as movement from one dominant logic to another. There is a dominant logic but the other logics may exist in the organizational field. Once a logic become dominant then stability is established in the field.

\section{Multiple institutional logics}

Multiple logics have been identified in publication in the last two decades. Coexisting logics identified in transformation process have been presented as an impermanent phenomenon as this can be replaced by new logics. The old logic that is supported by incumbent actors are changed by new logics when transition are success in the organization. During transition period, competing logics co-exist until one logic wins and it becomes dominant in the field (van Gestel \& Hillebrand 2011; Thornton et al. 2012). These all studies showed that there is power relations arena among actors during translation process when some actors may occupy advantaged position than the others. Field-level actors facilitated replacement of one dominant logic with another as they win to bring their values and beliefs with actions at all organizational levels. Conrath-Hargreaves and Wüstemann (2019) proposes coexistence of business logics, academic logics and government logics in German higher education institution. The old logics still exist in the field, in the same time, conflicting among key actors is likely occur because 
challenger actors support a new logic when a new logic is introduced to an established field.

Despite the multiple logics have discussed in studies of organisational reform, very exceptional studies that focus on the interaction of logics in the field. Moreover, several publications were identified in other contexts seem far from higher education accountability reform area. One of publication related to internalization reform of higher education at French business school can be notified in the work of Kodeih and Greenwood (2014) who focus on the experiences of French's business school to response institutional complexity. The rest of researches mostly were conducted in other public sector organization or other focus areas such as cities in USA by Lounsbury (2007); health care institution by Reay and Hinings (2009); and practices of knowledge production by Swan et al., (2010). Refer to the previous studies, this study categorizes emerging meaning of practices of accountability reform in the context of study during data collection. As a grounded theory study, institutional logics were employed as one of theoretical lens since generating open categories.

Scott \& Meyer (1994) emphasize complexity of institutional environment and organisation as there is possibility that multiple logics exist in organisations. Many organisational field may have two or more competing belief systems practicing by the actors of organisation. This multiple logics may compete or conflict (See Reay \& Hinings, 2005; Lounsbury, 2007; Purdy \& Gray, 2009). One logics become dominant then it means the change essentially occur in the field. In the context of public university, Bastedo (2008) identified convergent institutional logic when institutional logics have legitimacy among multiple types of actors within organizational fields. However, researchers in this research area are very limit to give empirical attention to how logics change. In the perspective of current institutionalist, institutional logics are determined by the institutional work carried out by actors in the field and institutions are fundamentally dependent on human action (Lawrence and Suddaby, 2006).

\section{The role of agent in institutional change}

The way of logic change may depend on the role of agent in institutional change. Agent are assumed as active actors instead of passive players who involve in process of the change. They may accept, reject or combination of both during the reform process, hence the way of agent to response the change may also differ depend on their logics. Lawrence and Suddaby (2009) proposed three broad categories of 
institutional work: creating, maintaining, and disrupting institutions. Action of individuals and organizations may have purposive action aimed at creating, maintaining and disrupting during institutional change. Lawrence and Suddaby (2006) argued that the theory of institutional work refocus traditional institutionalist concerns of how social structure affect action, reorienting to understanding how action affects institutions. The concept of institutional work was developed by institutionalist scholars based on as an important perspective that action of individuals and organizations must have objectives in institutional change. The studies that employ the institutional work perspectives could be instanced in the work of Zietsma and Lawrence (2010) researching in British Columbia coastal forest industry transformation; Gawer and Phillips (2013) investigating the Case of Intel's transformation to platform leader; and Marti and Fernandez (2013) learning from Holocaust case; and Helfen and Sydow (2013) focusing negotiations as a form of institutional work.

Moreover, institutional logics perspective often ignore perceptual component that operate cognitively at the level of individuals (Suddaby, 2010). The relationship among organizations and the fields in which they operate have been conventionally emphasized by previous institutionalists who focusing on how institution govern action (e.g Lawrence and Suddaby, 2009; Zietsma and Lawrence, 2010; Lawrence, Leca and Zilber, 2013). In the opposite perspective from the structuralism above, the concept of institutional work describes "the purposive action of individuals and organizations aimed at creating, maintaining and disrupting institutions" (Lawrence \& Suddaby, 2006, p.220). Differ from institutionalist who focus on how actions are shaped by social structure, institutionalist scholars recently take into account the role of agent in the change process more focusing on heteroganity of institutionalization process.

we have importantly identified four kinds of institutional work that have to be performed simultaneously for an organization to be able to successfully influence the logic it wants to change. It is not enough to stimulate change at the field level as organizations must respond effectively to the changes in logic as they occur. Organizations involved in trying to change the logic that characterizes their field will therefore need sufficient resources and skills to manage both internal and external institutional work simultaneously (Gawer and Phillips, 2013). 
For that reason, most current institutionalist offers more attention on the important potential connections between institutional work and institutional logics. My study investigates the emerging themes using institutional logics perspective as theoretical lens. The theory of institutional logics has been utilized as a lens during the stage of axial and selective coding for explaining the substantive theory generated from data. The theory was employed to provide qualitative analysis which focused on explaining the emergent themes rather than to frame hypothesis. The data analysis that adopt Straussian qualitative research method allow to compare and contrast data through investigating meaning of actions among actors in the three fields of study. The analysis illuminates the existence of various institutional logics as responses of accountability reform in the observed PTN BH. Initially, the study categorizes inductively qualitative data during initial open coding. Further, the emergent initial codes are categorized by various institutional logics using framework of Sinclair (1995) consist of personal, professional, managerial and political accountability utilized iteratively during generating open and axial categories. Subsequently, the framework of Sinclair (1995) are combined with perspective of internationalization level of higher education explained by Marginson (2006) and Mok (2007). Higher education internationalization could be interpreted as higher logic compatibility resulting in lower conflict and improved performance (Battilana and Dorada, 2010). In contrast, less internationalization could be taken into account as moderate conflict where the conflict still exists during institutionalization process.

\section{RESULTS AND DISCUSSION}

Public university with high internalization and moderate conflict

One of the observed universities in Indonesia that perform high internationalization tend to have moderate conflict regarding their multiple logics such as divergent goals, values, and identities, as well as different strategies and practices for achieving the organizational goals. Conflict of multiple logics seem moderate as the universities have been reformed longer than the other two. The moderate conflict during internationalization could be investigated by looking at consistency of their explicit vision of university compare with their motto/slogan as referred to the following quotes.

"To be excellent and innovative world class university, imbued with nation's cultural values based on Pancasila as the state ideology and dedicated to the nation's interest and humanity " (Vision statement of UG).

In line with the vision, UG renewed their slogan since become autonomous public 
university labelled as PTN BH stated the motto: "locally rooted and globally respected".

The slogan of UG has a meaning that all university's members should not only understand and appreciate the local culture but also being respected in international level. The word "globally" indicate that the university clearly declare the internationalization goal as consistent with the vision. The spirit of internationalization clearly displays in their motto or vision compare to other observed universities which seem quite reluctant to express or implicitly declare the internationalization goal with no word of global or similar words.

We therefore classify this type of university as an observed organization with high internationalization and moderate conflict (see Table I). Conflict is likely to be less due to having high centrality during accountability reform. The value of UG's slogan has been entrenched to the level of individual among university members. Most of academic members easily memorize it as the slogan are mostly written in all printed public document or media such as university's official souvenir, agenda book, etc. The university's members also believe that internationalization goals of university have been represented in every faculty/schools' vision derived from the university's vision. The international achievement of the top 300 world rank is not only becoming one of the best university in Indonesia but also bringing the local wisdom and culture still exist in higher educational process. This achievement consistent with their motto: "locally rooted and globally respected". Besharov \& Smith (2014) argues that the multiple logics are instantiated in their mission, strategy, structure, identity, and core work practices and are also likely to be represented among members, with no clear hierarchy between logics.

Public university with less internationalization and extensive conflict We categorized the other two observed public universities as organisations with less internationalization and extensive conflict. Similar to the previous categorization, the analysis were conducted inductively generated from data. We identify the organisations which relatively display low compatibility and low centrality. Low compatibility means that logics offer inconsistent implications for organizational action, leading actors to grapple with divergent goals and divergent means of achieving their organisational goals (Besharov and Smith, 2014).

UD and UA are the universities in Indonesia that currently exclude from the top 500 QS world rank. Despite less 
internationalization, UD and UA Moreover, multiple institutional logics' experience early development and many conflicting logics occur during the reform. During observation, UD was a second year of the reform while UA was a third year of the reform implementation.

Accountabilities' Responses in Various Level of Institutional Logics responses of accountability reform in the observed universities indicate particular relation between level of internationalization with its degree of institutional conflict during the reform and types of accountability as presented in the table I below.

Table I

Accountability Responses in Various Level of Institutional Logics

\begin{tabular}{|c|c|c|c|c|}
\hline & \multicolumn{4}{|c|}{ Level analysis of logics and accountability types } \\
\hline & \multirow{2}{*}{\multicolumn{2}{|c|}{ Individual Level }} & \multicolumn{2}{|l|}{ Organizationa } \\
\hline & & & 1 Level & Social Level \\
\hline $\begin{array}{l}\text { Internationalization } \\
\text { and conflict level }\end{array}$ & $\begin{array}{l}\text { Personal } \\
\text { accountabilit } \\
\text { y logic }\end{array}$ & $\begin{array}{l}\text { Professional } \\
\text { accountabilit } \\
\text { y logic }\end{array}$ & $\begin{array}{l}\text { Managerial } \\
\text { accountability } \\
\text { logic }\end{array}$ & $\begin{array}{l}\text { Public } \\
\text { accountability } \\
\text { logic }\end{array}$ \\
\hline $\begin{array}{l}\text { Less } \\
\text { internationalization } \\
\text { with extensive conflict }\end{array}$ & Complying & Imitating & Balancing & Aligning \\
\hline $\begin{array}{l}\text { High } \\
\text { internationalization \& } \\
\text { moderate conflict }\end{array}$ & Imitating & Bargaining & Dominating & Aligning \\
\hline
\end{tabular}

Source: author

Referring to the data of three observed organization. Personal accountability is universities, responses of various institutional logics occur in individual level, organizational level and in the social level.

\section{Individual level}

The are two types of accountability logic at individual level. The accountability types consist of personal and professional accountability logic. Personal accountability logic could be related to someone's value in explaining reason of conduct that have been internalized in an driven by adherence to internalized moral and ethical values (Sinclair, 1995, p230). Some people in academic life still think in terms of what they consider to be their duty, who do their academic duty independently without any external constraint or coercion, but perceiving their duty as honor, loyalty, or any spirits required to be a good scholar of the university (Trow, 1996).

In university with less internationalization, most observed actors explain that their belief related to personal accountability are 
concentrated on complying to the internalization norms of higher education. They always eager to satisfy the new norm that lecturer of PTN BH should contribute to the achievement of university's key performance indicators as a new spirit among academician. Refer to DU and UA respondents, the norms consist of demand for producing more international publication in reputable journal, having more research collaboration with international scholar and experiencing employee performance based incentive. They always require their actions to comply with the new norm as PTN BH represented in the following quote.

"With new targeted individual performance, I must try to follow new demand for publishing more in reputable international journal although this may be hard for everybody" (Academic member of $D U)$

The academic member at less internationalization organizations always belief that conflict between new logic and old managerial logics during transformation could be condensed effectively as long as individual actions comply to the norm of internationalization of higher education. This finding seems similar to the work of Gebreiter and Hidayah (2019), Aksom, (2018), and Conrath-Hargreaves and Wüstemann
(2019) which explain how multiple logics have been responded by individual in the education institutions.

We also identify different institutional responses identified in $\mathrm{UG}$ as higher international level compared to the other observed university. Complying to internationalization norm does not occur explicitly instead of imitating other strategies from higher level of international universities. The actors highly consider international benchmark by looking at other world class universities' tactics, employed by their actors, that able to compete effectively in global competition as represented in the quote below.

"I believe that spirit for escalating individual collaboration between international researchers are the successful strategies for accelerating world class level. One of the example is collaboration in citation" (Academic member of $U G$ )

Personal accountability for nonacademic member, such as administrators, principally follow the response of academic member formed by their institutional logics. Nonacademic staff of UG tend to support academic staff in complying to internationalization demand while imitating the strategies from other world class universities' personnel that were identified in DU and UA. 
Despite personal accountability, key actors also play professional accountability which exists in the area of academic members in observed universities. Professional accountability represents the sense of duty that one has as a member of a professional or expert group, which in turn occupies a privileged and knowledgeable position in society (Sinclair, 1995, p.229). This area accountability logic particularly points out the belief of academic member in playing their role inside organization. Differ from personal accountability, the observed participants individually practice professional accountability as they commit to their professional performance. As member of academic personnel, national lecturer certifications are mostly become basic targeted performance of individual area while ability to publish in reputable journal, such as Scopus journal, are the next agenda of the staff.

Professional accountability logic practiced by academic staff in the context of less internationalization organizations, likely in DU and UA, seem imitating the professional value of their senior lecturer. They often criticize the demand for publishing their written articles in reputable international journal, targeted by top manager of the universities, as part of internationalization objective. Following their senior, they often questioning the importance of publication number when the university cannot play their significant contributions to elucidate problems arise in society. The critique for being university with intensive publication in international journal rather than higher education institution that may contribute more in resolving the problems of society are represented in the quote below.

"In my perspective, academic member has responsibility in providing problem solving to the community and spreading knowledge through publication. Sometimes, this option may contradictory in everyday life of researcher. To be honest, I prefer to be famous due to real world solution maker likely my senior instead of well-known in international publication. (Academic member of $U A$ )

Imitating professional value as accountability presence performed by academic staff described above may not occur intensively in university with high internationalization level. In higher institutionalization university such as UG, professional value of individual accountability tends to develop their bargaining position in order to get better financial compensation from their working place. Bargaining is the form of institutional logics arises from individual perspective as reaction the existence of professional accountability logic. The observed actors at UG commit to 
professional performance, including their international publication achievement, while struggling either with their financial or nonfinancial compensation rewarded by the university.

\section{Organizational level}

Differ from individual level, the accountability types that are practiced at organizational level can be closed to the concept of managerial accountability. Administrators need to exercise discretion in performing their duties, and should be held accountable in terms of several mutually complementary standards. They should be able to control input and output during budget realization. Sinclair (1995, p.227) argue that both managerial accountability and administration accountability are played in the same time in the public sector context. Reason of conduct are viewed as formalization of control mechanism through assessing managerial compliance to a rule of law and specified procedures (Kenneth, P, 1972). In term of financial reporting, top management should comply to specific accounting standard for PTN BH, established by Indonesia Accountant Association, directed through higher education ministerial.

We identify different institutional responses related managerial accountability logic among observed PTN BH in organizational level. We categorize two responses labelled as balancing and dominating practiced in universities with less internationalization and high internationalization respectively. Balancing is a practice when executive manager inside university always take into account problem of competing various logics between involved unit's actor. The practice can be illustrated in the following quote.

"It is almost impossible to strictly apply accountability reform in the beginning period of PTN BH implementation. Various stakeholders bring their own value and belief regarding world class university perspectives. No choice, managerial stability in early reform is more important rather than progressive achievement". (One of Dean in UD)

Meanwhile, dominating is a practice where management have more ability to influence other counterpart such as between executive manager and senate. In the case of university with high internationalization \& moderate conflict such as UG, practice of cost standardization for budgeting purpose are often strictly influenced and recommended by member of nonacademic senates who have authority in budget approval. Dominating actions could be illustrated in the following quote.

"in my university, one of new phenomena is that nonacademic senate (MWA) request to regulate the standard cost as they want to 
get more control in managerial policy". (Vice Rector of $U G$ )

Nonacademic senate who have role in controlling executive manager mostly have ability to influence the policy of Rector. However, nonacademic senate may not have adequate power to influence the top executive manager when high internationalization level has been achieved. In this case, dominating move from the nonacademic senate area to the executive manager.

\section{Social Level}

The last response of accountability logics reform could be identified in the social level. This is the area of accountability logic that exclude from personal and managerial accountability logic practiced in the PTN BH. In the social level, norm, value and belief as autonomous state university, created by government, have determined socially the strategic decision inside organizations. Thornton and Ocasio (1999) illustrated the existence of economic forces in higher education publishing context which viewed institutional logics as the norms, values, and beliefs that structure the cognition of actors in organizations, and provide a collective understanding of how strategic interests and decisions are formulated. In line with this perspective, Thornton, (2001) argued that institutional logics are historically variant and shaped by economic and social structural changes in market logics of control. Depart from these references, this study proposes social level views as macro level analysis which may illuminate how accountability logics are practiced by actors in the context of study.

Differ from the other accountability response, public accountability logic is a macro value of PTN BH as higher education institutions which close to social structural change. It is likely an effort to link the values of the new organizational form with values held in the broader social context within which the organization exists (Suddaby and Greenwood, 2005). Public accountability logic was conceptualized due to many efforts have been done by all observed PTN BH with regard to comply the new reform value for being part of the top 500 world class university. Similar to a previous academic work, Purdy and Gray (2009) ever illustrate institutional entrepreneur from extant institutions at the field level (such as state judiciaries, executive offices, and legislative agencies) as an effort to tailor the national logics to the need of their states. In this research, PTN BH are also treated as field level which have national pressures to deal with the value of becoming the top 500 world class university.

Being the top 500 world class university is the strategic mandate of PTN BH regulated by Indonesia government. National 
regulation prepared by Ministry of higher education require the university to prepare new governance system that are more autonomous in decision making. The new system delegates the decision making for new organizational structure, human resources recruitment, higher education service, innovation, financing and asset management to PTN BH. Despite emergent spirit to be world class university, PTN BH also take into account the existence of contradictory issues from national regulation of PTN $\mathrm{BH}$ that may create struggling for compliance in constructing the new governance system of PTN BH. This is becoming social field of accountability practice among PTN BH.

The social level identified in this study indicates a very specific response type of practice related to public accountability logic. Managerial decision in all PTN BH always consider the need for collaboration among organizations of PTN BH. This could be acknowledged in all observed PTN BH investigated from the perspective of both academic member and managerial personnel. They always eager and expect to do institutional collaboration among PTN $\mathrm{BH}$ for being competitive in world class challenge.

"We should encourage national collaboration in citation among researchers' published articles from PTN
BH. This strategy is hopefully very effective in increasing international recognition of our institution". (Academic member of UD).

This collaboration spirit was also identified in the interaction among representative of PTN BH during official meeting arranged periodically by national secretariat office of PTN BH. The spirit could be represented in the effort to influence government regulation draft by working together in formulating national recommendation as the following quote.

"We have to formulate and deliver our draft for government regulation regarding problem solving of PTN BH governance system. There are three scope of issues urgently to be discussed: human resources, finance and asset" (Finance director of UA) As a summary, all observed universities display a unique response of public accountability logic labeled as aligning among PTN BH.

\section{Professional versus old managerial logics}

The first two common guiding decision making that often compete each other, identified all observed universities, are professional logics and old managerial logics. The former could be related to academic professional logics which are identified from academic personnel who have pressure for generating more international publications and excellent 
higher educational services. Meanwhile, the later could be viewed as institutional identity practiced by administrators who are still belief regarding compatibility of previous financial system to support internationalization agenda. These two logics always have contradictory perspective as represented in the following quote expressed by academic staff and administrator respectively.

"I think they (administrators) should change their approach in ruling financial procedures for reporting purposes. They often focus on legitimacy purposes referred to the previous regulation before implementing PTN BH". (Academic member of UD).

\section{Professional versus national political logic}

Another conflicting institutional logic regarding the reform is between professional logic and national political logic. The contradictory logics have been identified in all observed PTN BH when professional value of academic member experience incompatibility with national agenda. Number of published articles in reputable international journal has become personal pressure for every academic member with regard to achieve the ministry target. Meanwhile, academic members have confidence in their daily job as a lecture and researcher who always hold their fundamental professional value in delivering knowledge to their students and local community. They often questioning and criticizing the benefit of published article in reputable international for local community and the benefit for their students as represented in the quote below. "I don't believe that this current policy to academic member (in publishing article to international journal) have significant impact to our local community. This is kind of impact from industrial pressures experienced by most universities in the world". (Academic member of UG).

\section{National political versus old managerial logic}

Together with previous conflicting logics discussed above, this study also offers another important conflicting logic that are national political logic versus managerial logic. The national agenda in accelerating global competitive index is one of the biggest issues in Indonesia. Therefore, most of Indonesia higher education national policies are focused to support this national objective. As a result, PTN $\mathrm{BH}$ are expected to be more independent in funding and projected to be able in managing the organizational resources likely in private organization. In this case of the study, administrative staff of PTN BH who are mostly government employee seem maintain their bureaucrats' standpoint 
which clearly incompatible with the reform. The old managerial logics that is contradictory with the national political logic could be illustrated in the following quote.

"new managerial system is more friendly to career of academic staff rather than to administrative staff. PTN BH have created more new managerial positions for academic member.... we (administrators) may not have any opportunity to get more benefit due to the new managerial system focus on internationalization agenda" (administrators of UD)

\section{Creating Institution in Competing}

Institutional Logics during

\section{Accountability Reform}

As grounded theory study, this research eager to generate both the substantive and formal theory. The former is a theory that inductively generated form data and could be utilized to explain central phenomenon of the study referring to its specific contextual background. In this case of PTN $\mathrm{BH}$, the existence of competing institutional logics clearly illuminates problem of reform when no dominant logics over the other. The substantive theory explains various responses of accountability transformation in the context of PTN BH. Meanwhile, the latter is a theory which is expected to provide possible theoretical explanation of accountability transformation in broader context.

As explained in the previous discussion above, the substantive theory was accountability responses in various level of institutional logics. The substantive theory explaining the central phenomenon was generated from emergent themes during the process of axial coding as presented in the appendix of this paper. Despite generating inductively a substantive theory, this study further also attempts to generate a formal theory named as "Creating Institution in Competing Institutional Logics of Accountability Reform".

The formal theory was generated by initially looking for theoretical lens that compatible in explaining the substantive theory. Institutional work theory of Lawrence and Suddaby (2006) has been employed to interpret the substantive theory generated inductively from data. The responses of accountability reform in various level of institutional logics are relatively similar to a form of institutional work. Lawrence and Suddaby (2006, p.220) promotes institutional work as " the sets of practices through which individual and collective actors create, maintain and disrupt the institutions of organizational fields". The finding of this research which display the responses of accountability reform in various level of institutional 
logics that have been interpreted similar to creating institution rather than practices of maintaining and disrupting. A generic theoretical framework generated iteratively from data and relevant literature could be presented in the following figure 1.

\section{Figure 1}

Creating Institution in Competing Institutional Logics of Accountability Reform

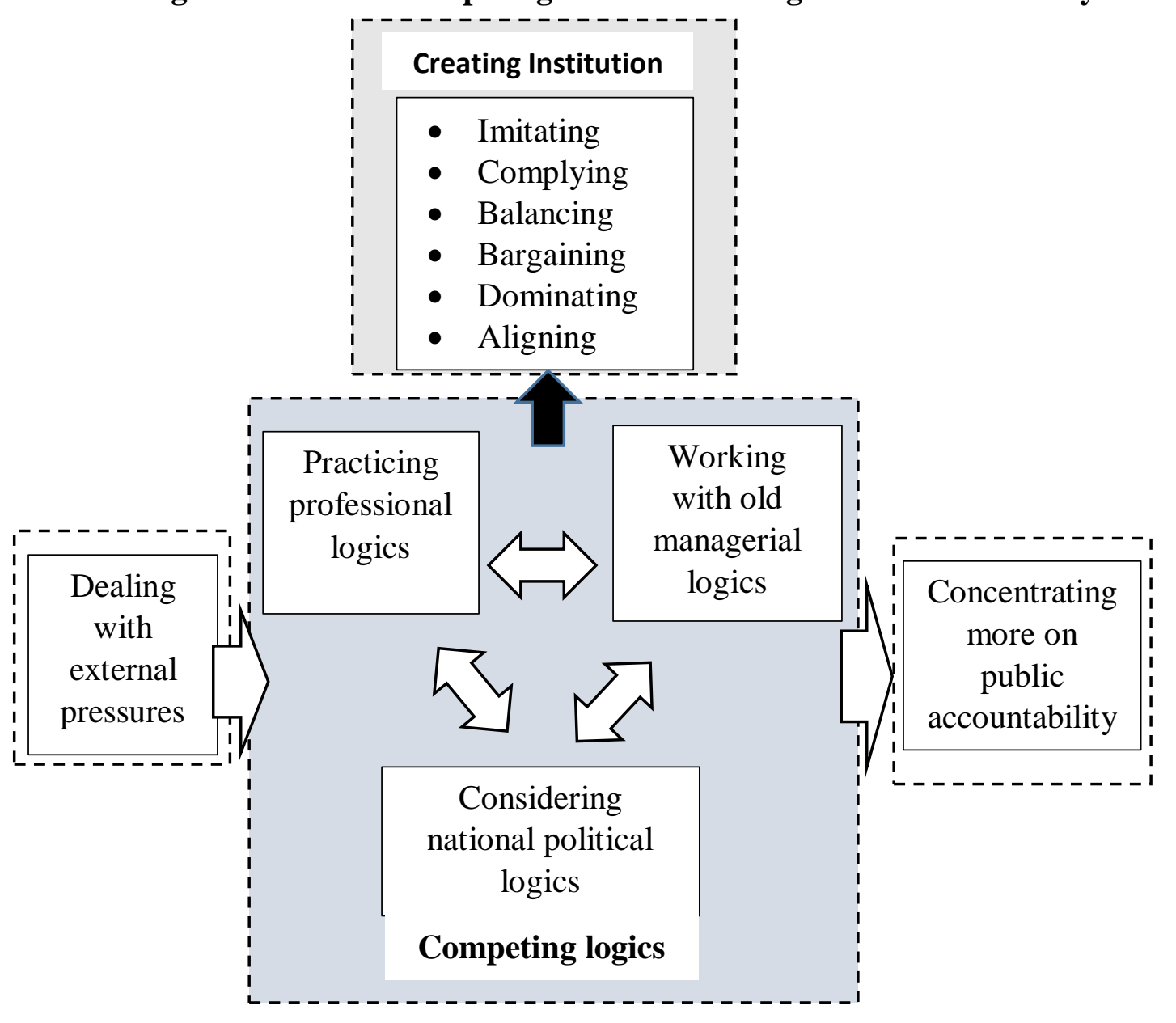

As researcher of this study, I found practices of imitating among actors of PTN $\mathrm{BH}$ similar to the form of mimicry which was explained by Lawrence and Suddaby (2006, p.221) as associating new practices with existing sets of taken-for-granted practices, technologies and rules in order to ease adoption. Next, I also found that practice of complying could be compared with the form of creating institution label by
Lawrence and Suddaby (2006, p.221) as constructing normative networks. Practices of complying are quite similar to the form of institutional work practices which constructing of inter-organizational connections. Actor develop the interorganizational connections through which practices become normatively sanctioned and which form the relevant peer group 
with respect to compliance, monitoring and evaluation.

Further, I also view that practice of balancing, bargaining, and dominating observed in this study are close to a form of institutional work involves activity directed toward defining the construction of rule systems. The three form of identified institutional form clarify the existence of the practices to define boundaries of membership or create status hierarchies within a field. The last, practice of aligning was taken into account as part of creating institution that similar to the work of Reay and Hinings (2009) illustrating howing that competing logics can co-exist and rivalry between logics can be managed through the development of collaborative relationships. This finding also confirm the form of constructing identities which focusing on the relationship between an actor and the field in which that actor operates. During the reform, all of overserved PTN BH focused on public accountability rather that financial and other accountability as the existence of competing institutional logics among actors in the organizational field.

\section{CONCLUSIONS AND SUGGESTIONS}

The findings of this research conceptually explain the existence of competing institutional logics during the accountability reform of PTN BH. The competing logics also create practices labeled as creating institution in accountability reform of PTN BH. There are six responses type identified in this grounded theory study when these all responses could be interpreted by employing theory of institutional work developed by Lawrence and Suddaby, (2006) as part of institutional form called as creating institution. The competing institutional logics in the organizational field illustrate that no dominant logic exist then the change process still continue and the reform have not finished yet. The accountability reform is driven by external pressures named as world class university agenda. This study also categories type of responses comparing between relatively high internationalization and low internationalization. Finding of the study clarify that practice of accountability depend on its context and may not be generalized. In this case, more concentration on public accountability are become consequence of creating institution in the situation of competing institutional logics. Moreover, contribution of this study relate to development of institutional work theory that filling the knowledge regarding creating institution. Moreover, practical knowledge resulted from this study is that the unique accountability reform in PTN BH. Despite competing logics are still occur, various responses of accountability 
reform may contribute to the reform strategy during implementation of new government structure. Finally, this study also have contribution in the usage of grounded theory method in public sector accounting research.

\section{Appendix 1}

\section{CATEGORIES' DEVELOPMENT}

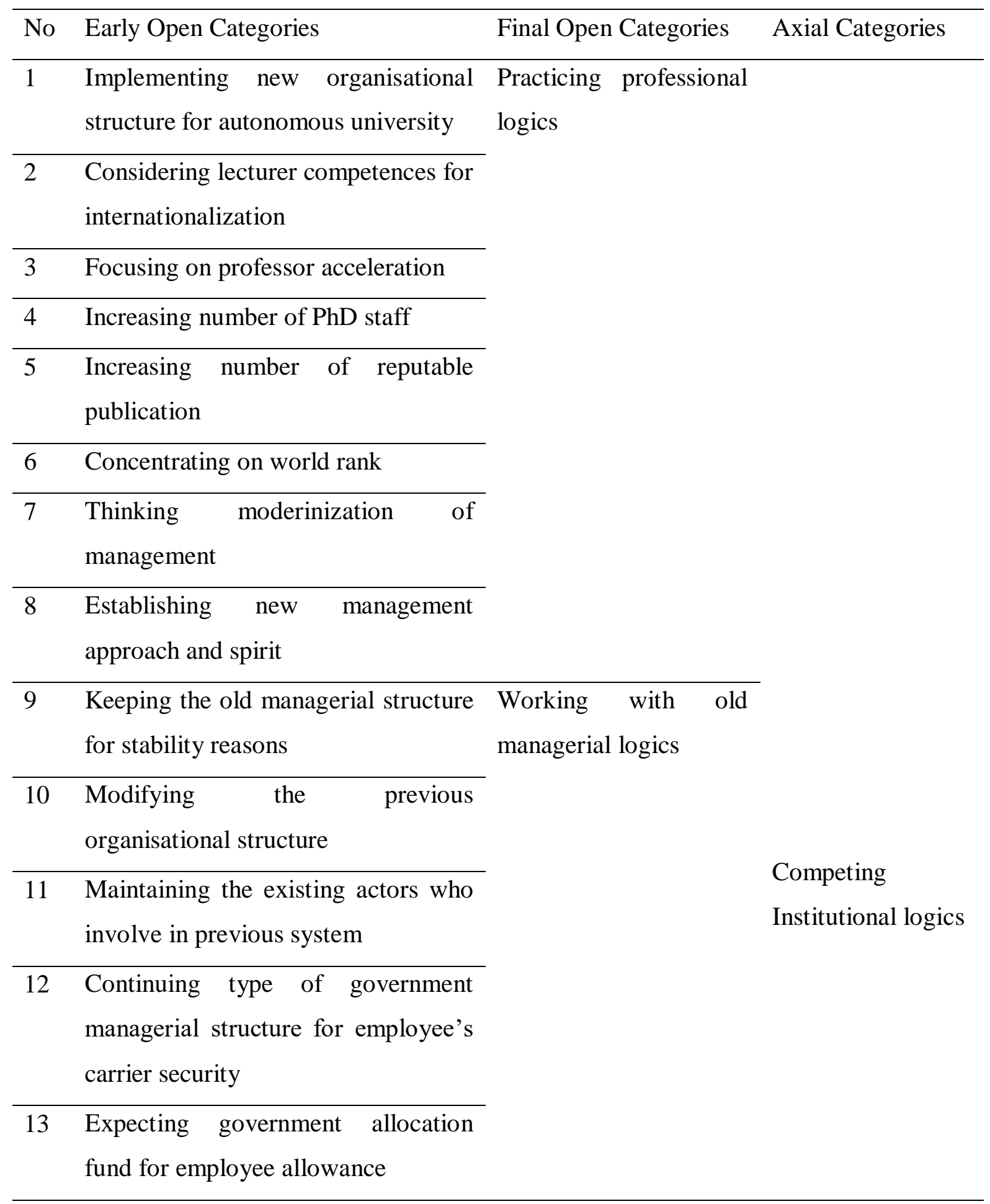

22 RESPONSES OF ACCOUNTABILITY TRANFORMATION PRACTICED IN MULTIPLE LEVEL OF INSTITUTIONAL LOGICS FOR BEING AUTONOMOUS STATE UNIVERSITIES IN INDONESIA 


\begin{tabular}{|c|c|c|c|}
\hline No & Early Open Categories & Final Open Categories & Axial Categories \\
\hline 14 & Keeping on cash basis accounting & & \\
\hline 15 & $\begin{array}{l}\text { Struggling for developing } \\
\text { competitive advantage of the country }\end{array}$ & \multirow[t]{6}{*}{$\begin{array}{l}\text { Considering national } \\
\text { political logics }\end{array}$} & \\
\hline 16 & $\begin{array}{l}\text { Conflicting interpretation of national } \\
\text { regulation for PTN BH }\end{array}$ & & \\
\hline 17 & $\begin{array}{l}\text { Fulfilling internationalization } \\
\text { demand of national leader }\end{array}$ & & \\
\hline 18 & $\begin{array}{l}\text { Learning from other country for } \\
\text { internationalization agenda }\end{array}$ & & \\
\hline 19 & Maintaining services for poor student & & \\
\hline 20 & $\begin{array}{l}\text { Increasing revenue generating } \\
\text { activities (RGA) from non-tuition fee }\end{array}$ & & \\
\hline 21 & $\begin{array}{l}\text { Struggling in understanding different } \\
\text { perspectives of national regulation }\end{array}$ & \multirow{5}{*}{$\begin{array}{l}\text { Collaboration among } \\
\text { the member of PTN BH } \\
\text { (aligning) - part the } \\
\text { form of creating } \\
\text { institution }\end{array}$} & \\
\hline 22 & $\begin{array}{l}\text { Working together to endorse national } \\
\text { regulatory amendment }\end{array}$ & & \\
\hline 23 & $\begin{array}{l}\text { Strengthening the connection } \\
\text { between PTN BH members }\end{array}$ & & \\
\hline 24 & $\begin{array}{l}\text { Swapping the good experience among } \\
\text { universities }\end{array}$ & & \\
\hline 25 & $\begin{array}{l}\text { Negotiating with government through } \\
\text { PTN BH members' arrangement }\end{array}$ & & \\
\hline 26 & $\begin{array}{l}\text { Learning the governance structure } \\
\text { from the former universities }\end{array}$ & \multirow{4}{*}{$\begin{array}{l}\text { Complying and } \\
\text { imitating - part the form } \\
\text { of creating institution }\end{array}$} & \multirow{4}{*}{$\begin{array}{l}\text { Creating institution } \\
\text { Imitating } \\
\text { Complying } \\
\text { Balancing } \\
\text { Bargaining } \\
\text { Dominating } \\
\text { Aligning }\end{array}$} \\
\hline 27 & $\begin{array}{l}\text { Adapting the organisational structure } \\
\text { of other universities }\end{array}$ & & \\
\hline 28 & $\begin{array}{l}\text { Modifying the policy of other } \\
\text { universities }\end{array}$ & & \\
\hline 29 & $\begin{array}{l}\text { Reworking succesfull strategy of } \\
\text { former universities }\end{array}$ & & \\
\hline
\end{tabular}




\begin{tabular}{|c|c|c|c|}
\hline No & Early Open Categories & Final Open Categories & Axial Categories \\
\hline 30 & $\begin{array}{l}\text { Learning each other from the } \\
\text { mistakes }\end{array}$ & & \\
\hline 31 & $\begin{array}{l}\text { Absorbing problem solving } \\
\text { experiences of other universities }\end{array}$ & & \\
\hline 32 & $\begin{array}{l}\text { Comparing the achievement of other } \\
\text { universities }\end{array}$ & $\begin{array}{l}\text { Contesting for being } \\
\text { better world rank }\end{array}$ & \\
\hline 33 & $\begin{array}{l}\text { Suspecting the advanced university } \\
\text { regarding undisclosed startegy }\end{array}$ & $\begin{array}{l}\text { through the practice of . } \\
\text { balancing, bargaining, }\end{array}$ & \\
\hline 34 & $\begin{array}{l}\text { Promoting distinctive innovation to } \\
\text { the other }\end{array}$ & $\begin{array}{l}\text { and dominating in } \\
\text { organizational field }\end{array}$ & \\
\hline 35 & $\begin{array}{l}\text { Detecting the effort and result of other } \\
\text { universities for internationalisation }\end{array}$ & & \\
\hline 36 & $\begin{array}{l}\text { Strengthening the outcome based } \\
\text { planning }\end{array}$ & & \\
\hline 37 & $\begin{array}{l}\text { Internationalization agenda from } \\
\text { national policy }\end{array}$ & $\begin{array}{l}\text { Concentrating more on } \\
\text { public accountability }\end{array}$ & \multirow{2}{*}{$\begin{array}{l}\text { Concentrating } \\
\text { more on public } \\
\text { accountability }\end{array}$} \\
\hline 38 & $\begin{array}{lll}\text { Pressures for } & \text { international } \\
\text { publication } & & \\
\end{array}$ & \multirow{4}{*}{$\begin{array}{l}\text { Dealing with World } \\
\text { Class } \quad \text { University }\end{array}$} & \\
\hline 39 & $\begin{array}{l}\text { Number of international students } \\
\text { demand }\end{array}$ & & $\begin{array}{lr}\text { Dealing } & \text { with } \\
\text { World } & \text { Class }\end{array}$ \\
\hline 40 & Financial autonomy & & University \\
\hline 41 & Adopting new governance structures & & Pressures \\
\hline
\end{tabular}

\section{REFERENCES}

Abdul-Rahman, A. R. and Goddard, A. (2003) 'Accountability verstehen: A study of accounting in state religious councils in Malaysia', in Discussion Papers in Accounting and Finance.

Ahrens, T. (1996) 'Styles of accountability',
Organizations and Society, 21(2/3), pp. 139-173.

Aksom, H. (2018) 'Academics' experience of contradicting institutional logics of publishing', International Journal of Educational Management, 32(7), pp. 1184-1201. 
'Building Sustainable Hybrid

Organizations: the Case of

Commercial

Microfinance

Organizations', Academy of

Management Journal, 53(6), pp. 1419-1440.

Besharov, M. L. and Smith, W. K. (2014)

'Multiple Institutional Logics in

Organizations: Explaining Their

Varied Nature and Implications', Academy of Management Review. Academy of Management, 39(3), pp. 364-381.

ter Bogt, H. J. and Scapens, R. W. (2009)

'Performance Measurement in Universities: A Comparative Study of Two A\&F Groups in the Netherlands and the UK', SSRN Electronic Journal, 1, pp. 1-43.

Budding, G. T. (2004) 'Accountability, environmental uncertainty and government performance: Evidence from Dutch municipalities', Management Accounting Research, 15, pp. 285-304.

Catasús, B. and Grönlund, A. (2005) 'More peace for less money: Measurement and accountability in the Swedish armed forces', Financial Accountability \& Management, 21(4), pp. 467-484..

Chua, W. F. (1988) 'Interpretive sociology and management accounting research-a critical review', Accounting, Auditing \& Accountability Journal, 1(2), pp. 5979.

Conrad, L. (2005) 'A structuration analysis of accounting systems and systems of accountability in the privatised gas industry', Critical Perspectives on Accounting, 16, pp. 1-26.

Conrath-Hargreaves, A. and Wüstemann, S. (2019) 'Multiple institutional logics and their impact on accounting in higher education: The case of a German foundation university', Accounting, Auditing and Accountability Journal, 32(3), pp. 782-810.

Coy, D. and Pratt, M. (1998) 'An insight into accountability and politics in universities: A case study', Accounting, Auditing \& Accountability Journal, 11(5), pp. $540-561$.

Demirag, I. and Khadaroo, I. (2008) 'Accountability and value for money in private finance initiative contracts', Financial Accountability \& Management, 24(4), pp. 455-478.

Elharidy, A. M. et al. (2008) 'Using grounded theory in interpretive management accounting research', Qualitative Research in Accounting \& Management, 5(2), pp. 139-155. 
Ezzamel, M. et al. (2007) 'Discourse and institutional change: "Giving accounts" and accountability', Management Accounting Research, 18, pp. 150-171.

Friedland, R. and Alford, R. R. (1991) 'Bringing Society Back In: Symbols, Practices and Institutional Contradictions', in Powell, W. W. and Dimaggio, P. J. (eds) The New Institutionalism in Organizational Analysis. 1st edn. University Of Chicago Press, pp. 232-263.

Gawer, a. and Phillips, N. (2013) 'Institutional Work as Logics Shift: The Case of Intel's Transformation to Platform Leader', Organization Studies, 34(8), pp. 1035-1071.

Gebreiter, F. and Hidayah, N. N. (2019) 'Individual responses to competing accountability pressures in hybrid organisations: The case of an English business school', Accounting, Auditing and Accountability Journal, 32(3), pp. 727-749. doi: 10.1108/AAAJ-08-2017-3098.

van Gestel, N. and Hillebrand, B. (2011) 'Explaining Stability and Change: The Rise and Fall of Logics in Pluralistic Fields', Organization Studies, 32(2), pp. 231-252.

Goddard, A. (2004) 'Budgetary practices and accountability habitus: A grounded theory', Accounting, Auditing \& Accountability Journal, 17(4), pp. 543-577.

Goddard, A. (2005) 'Accounting and NPM in UK local governmentcontributions towards governance and accountability', Financial Accountability \& Management, 21(2), pp. 191-218.

Goddard, A. and Mzenzi, S. I. (2015) 'Accounting Practices in Tanzanian Local Government Authorities: Towards a Grounded Theory of Manipulating Legitimacy', The Public Sector Accounting, Accountability and Auditing in Emerging Economies, 15, pp. 109142.

Helfen, M. and Sydow, J. (2013) 'Negotiating as Institutional Work: The Case of Labour Standards and International Framework Agreements', Organization Studies, 34(8), pp. 1073-1098.

Hopper, T. and Powell, A. (1985) 'Making sense of research into the organizational and social aspecis of management accounting: A review of its underlying assumptions [1]', Journal of Management Studies, 22(5 September), pp. 429-465.

Hoque, Z. and Moll, J. (2001) 'Public sector reform-Implications for accounting, 
accountability and performance of state-owned entities-an Australian perspective', International Journal of Public Sector Management, 14(4), pp. 304-326.

Humphrey, C., Miller, P. and Scapens, R. W. (1993) 'Accountability and accountable management in the UK public sector', Accounting, Auditing \& Accountability Journal, 6(3), pp. 7-29.

Iyoha, F. O. and Oyerinde, D. (2010) 'Accounting infrastructure and accountability in the management of public expenditure in developing countries: A focus on Nigeria', Critical Perspectives on Accounting. Elsevier Ltd, 21, pp. 361-373.

Kenneth, P, M. (1972) Accountability in Higher Education. Washington, D.C: American Association .for Higher Education.

Kloot, L. (1999) 'Performance measurement and accountability in Victorian local government', International Journal of Public Sector Management, 12(7), pp. 565584.

Kluvers, R. (2001) 'Program budgeting and accountability in local government', Australian Journal of Public Administration, 60(2), pp. 35-43.

Kodeih, F. and Greenwood, R. (2014)

\author{
'Responding to Institutional \\ Complexity: The Role of Identity', \\ Organization Studies, 35(1), pp. 7- \\ 39.
}

Lawrence, T. B., Leca, B. and Zilber, T. B. (2013) 'Institutional Work: Current Research, New Directions and Overlooked Issues', Organization Studies, 34(8), pp. 1023-1033.

Lawrence, T. B. and Suddaby, R. (2006) Institutions and institutional work, The SAGE Handbook of Organization Studies.

Lawrence, T. B. and Suddaby, R. (2006) Institutions and institutional work. In S.R. Clegg, C. Hardy, T. Lawrence \& W.R. Nord (Eds.), Handbook of Organization Studies. 2nd edn. London: SAGE Publications.

Lawrence, T. B. and Suddaby, R. (2009) Institutional Work.

Lounsbury, M. (2007) 'A Tale of Two Cities : Competing Logics and Pratice Variation in the Professionalizing of Mutual Funds', The Academy of Managemnet Journal, 50(2), pp. 289-307.

Lounsbury, M. (2008) 'Institutional rationality and practice variation: New directions in the institutional analysis of practice', Accounting, Organizations and Society, 33(4-5), pp. 349-361. 
Marginson, S. (2006) Dynamics of national and global competition in higher education, Higher Education.

Marti, I. and Fernandez, P. (2013) 'The Institutional Work of Oppression and Resistance: Learning fromthe Holocaust', Organization Studies, 34(8), pp. 1195-1223.

Messner, M. (2009) 'The limits of accountability', Accounting, Organizations and Society. Elsevier Ltd, 34, pp. 918-938.

Michael N. Bastedo (2008) 'Convergent Institutional Logics in Public Higher Education: State Policymaking and Governing Board Activism', The Review of Higher Education, 32(2), pp. 209-234.

Mok, K.-H. (2007) 'Questing for internationalization of universities in Asia: Critical reflections', Journal of Studies in International Education, 11(3-4), pp. 433-454.

Monfardini, P. (2010) 'Accountability in the new public sector: A comparative case study', International Journal of Public Sector Management, 23(7), pp. 632-646.

Parker, L. D. and Roffey, B. H. (1997) 'Methodological themes back to the drawing board: Revisiting grounded theory and the everyday accountant's and manager's reality', Accounting,
Auditing and Accountability Journal, 10(2), pp. 212-247.

Purdy, J. M. and Gray, B. (2009) 'Conflicting logics, mechanisms of diffusion, and multilevel dynamics in emerging institutional fields', Academy of Management Journal, 52(2), pp. 355-380.

Reay, T. and Hinings, C. R. (2005) 'The Recomposition of an Organizational Field: Health Care in Alberta', Organization Studies, 26(3), pp. 351384.

Reay, T. and Hinings, C. R. (2009) 'Managing the Rivalry of Competing Institutional Logics', Organization Studies, 30(6), pp. 629-652.

Robinson, P. (2003) 'Government accountability and performance measurement', Critical Perspectives on Accounting, 14(1-2), pp. 171186.

Schaeffer, M. and Yilmaz, S. (2008) Strengthening local government budgeting and accountability. 4767.

Scott, W. R. (2014) Institutions and Organizations: Ideas, Interest, and Identities. 4th edn. SAGE Publications Ltd.

Scott, W. R. and Meyer, J. W. (1994) Institutional Environment and Organisations: Structural Complexity and Individualism. 
Thousand Oak, California: Sage Publications Inc.

Sinclair, A. (1995) 'The chameleon of accountability: Forms and discourses', Accounting, Organizations and Society, 20(2/3), pp. 219-237.

Strauss, A. L. and Corbin, J. M. (1990) Basic of Qualitative Research: Gounded Theory Procedures and Technique. Newburry Park, California: Sage Publications Ltd.

Suddaby, R. (2010) 'Challenges for Institutional Theory', Journal of Management Inquiry, 19(1), pp. 1420.

Suddaby, R. and Greenwood, R. (2005) 'Rhetorical Strategies of Legitimacy', Administrative Science Quarterly, 50(March).

Swan, J. et al. (2010) 'When policy meets practice: colliding logics and the challenges of "mode 2" initiatives in

'Strategic management accounting and sense-making in a multinational company', Management Accounting Research, 19, pp. 80-102.

Trow, M. (1996) 'Trust, markets and accountabiliy in higher education: a comparative perspective', Higher Education Policy, 9(4), pp. 309-324. the translation of academic knowledge', Organization Studies, 31(09 \& 10), pp. 1311-1340.

Thornton, P. H. (2001) 'Personal Versus Market of the Risk Theory Contingent A Historically of Acquisition', Organization Science, 12(3), pp. 294-311.

Thornton, P. H. and Ocasio, W. (1999) 'Institutional Logics and the Historical Contingency of Power in Organizations: Executive Succession in the Higher Education Publishing Industry, 1958-1990', American Journal of Sociology, 105(3), pp. 801-843.

Thornton, P. H., Ocasio, W. and Lounsbury, M. (2012) The Institutional Logics Perspective: A New Approach to Culture, Structure, and Process. OUP Oxford.

Tillmann, K. and Goddard, A. (2008)

Zietsma, C. and Lawrence, T. B. (2010) 'Institutional Work in the Transformation of an Organizational Field: The Interplay of Boundary Work and Practice Work', Administrative Science Quarterly, 55(2), pp. 189-221. 